\title{
Design for Monitoring Blood Pressure, Non-Invasive Blood Sugar, Weight, and Body Temperature Based on Internet of Things
}

\section{Rancang Bangun Monitoring Tekanan Darah, Gula Darah Non-Invasif, Berat, Dan Suhu Badan Berbasis Internet Of Things}

\author{
Muhammad Nur Fariz ${ }^{1}$, Jamaaluddin ${ }^{2}$ \\ \{nurfarizm12345@gmail.com ${ }^{1}$ jamaaluddin@umsida.ac.id\}
}

Program Studi Teknik Elektro, Fakultas Sains dan Teknologi, Universitas Muhammadiyah Sidoarjo

\begin{abstract}
In adults to the old age, check health conditions such as blood pressure, blood s ugar levels, and others are needed regularly. Medical devices generally only be operated by doctors. Healthcare companies always develop medical devices for efficiency in use and minimize costs in manufacture. In this study, researchers made a design for monitoring blood pressure, non-invasive blood sugar, weight, and body temperature based on the Internet of Things. This tool uses NodeMCU microcontroller, which processes sensor MAX30100 and DS18B20. The MAX30100 sensor is used to detect blood pressure and blood sugar non-invasive. By put finger index on the sensor, the results will display after 20 seconds. DS18B20 sensor is used to measure realtime body temperature by clamp the sensor to the armpit. Load Cell sensors and the HX711 module are used to measure body weight.Results on measurements on LCD $20 \times 4$ and android using the Blynk application with the internet.Test analysis with a compare of the manufacturer's standard tools. The results, accuracy of tool are $94.78 \%$ and 93,37\% in the measurement systole and diastole, 93,21\% in measuring blood sugar, 96,55\% in measuring body temperature, and 98,27\% in measuring body weight. The results on Android can display if there is an internet or wifi connection without place restrictions.
\end{abstract}

Keywords - Blood pressure; Blood sugar; NodeMCU; Internet Of Things

\begin{abstract}
Abstrak. Pada usia remaja sampai lansia pemeriksaan kondisi kesehatan meliputi tekanan darah, gula darah, dan sebagainya sangatlah diperlukan secara berkala. Alat kesehatan yang digunakan hanya bisa dioperasikan oleh dokter. Perusahaan yang bergerak dalam bidang kesehatan selalu mengembangkan alat medis guna efisiensi dalam pengguaannya dan meminimalisir biaya pembuatannya. Pada peneltian ini peneliti membuat Rancang Bangun Monitoring Tekanan Darah, Gula Darah Non-Invasif, Berat, Dan Suhu Badan Berbasis Internet Of Things. Alat ini menggunakan mikrokontroller NodeMCU, yang mengolah sensor MAX30100 dan DS18B20. Sensor MAX30100 digunakan untuk mendeteksi tekanan darah dan gula darah non-invasif. Dengan menepelkan jari pada sensor maka hasil pengukuran akan keluar dengan durasi 20 detik. Sensor DS18B20 digunakan untuk megukur suhu tubuh realtime dengan menempatkan sensor pada ketiak. Sensor Load Cell yang dilengkapi dengan modul HX711 digunakan untuk mengukur berat badan. Hasil pengukuran ditampilkan pada LCD $20 x 4$ dan android menggunakan aplikasi Blynk dengan koneksi internet. Analisa pengujian dengan perbandingan alat standart pabrikan. Hasil akurasi pada alat ini adalah 94,78\% dan 93,37\% dalam pengukuran systole dan diastole,93,21\% pada pengukuran gula darah, 94,78\% dan 93,37\% dalam pengukuran systole dan diastole, 96,55\% pada pengukuran suhu badan, dan 98,27\% untuk pengukuran berat badan. Hasil pada android bisa tampil jika terkoneksi internet atau wifi tanpa batas tempat.
\end{abstract}

Kata Kunci - Tekanan darah; Gula darah; NodeMCU; Internet Of Things

\section{Pendahuluan}

Structural Health Monitoring (SHM) merupakan sebuah pembahasan penilitian tentang pentingnya dalam meningkatakan keselamatan manusia dan mengurangi biaya dalam perawatan, permasalahan dari SHM yakni menghadapi tantangan secara berturut-turut dalam faktor lingkungan[1]dengan hal tersebut tercetus dalam menyelesaikan masalah penyakit utuk mendeteksi secara dini yakni diabetes mellitus (DM), hipertensi, hipoksia, serangan jantung dan suhu realtime tubuh manusia.

Diabetes Mellitus adalah penyakit dengan kelainan metabolisme yang diakibatkan oleh defek sekresi insulin, yang menyebabkan hiperglikemia (peningkatan konsentrasi di dalam darah) dengan gangguan karbohidrat, lemak, dan protein tubuh [2]. Dari tingkat prevalensi global penderita diabetes mellitus pada tahun 2017 sekitar 8,3\% dari keseluruhan penduduk yang berada di seluruh dunia. Kemudian pada tahun 2017 Internasional of Diabetic Federation memprediksi bahwa pada tahun 2045 akan meningkat sekitas $48 \%$ dari sebelumnya 425 juta kasus menjadi 629 juta kasus. Wilayah Asia Tenggara merupakan peringkat kedua prediksi peningkatan penderita diebetes milletus setelah Afrika.[3] 
Procedia of Engineering and Life Science Vol.1 No. 1 March 2021

Seminar Nasional \& Call for Paper Fakultas Sains dan Teknologi (SENASAINS $1^{\text {st }}$ )

Universitas Muhammadiyah Sidoarjo

Selain gula darah, pengukuran secara berkala dibidang kesehatan adalah pengukuran tekanan darah. Tekanan darah adalah tekanan yang terjadi pada dinding arteri. Tekanan ini dipegaruhi oleh beberapa faktor seperti curah jantung, ketegangan arteri, dan volume, laju serta kekentalan darah. Tekanan darah tinggi adalah salah satu faktor risiko untuk terjadinya serangan jantung, gagal jantung, stroke, aneurisma arterial, dan merupakan penyebab utama gagal jantung kronis[4][5].

Setelah tekanan darah, Pada tahun 2001 World Health Organization (WHO) mengklasifikasikan Indonesia dalam kategori A dalam identifikasi demam berdarah (DB), ini menunjukkan bahwa jumlah perawatan di rumah sakit dan kematian yang disebabkan oleh demam sangat tinggi.[6]

Dari permasalah mulai dari atas tersebut, sebelumnya pernah dikembangkan alat pendeteksi gula darah dengan teknik invasive, teknik invasive sendiri merupakan teknik yang sudah umum di masyarakat. Dimana teknik ini membutuhkan pengambilan darah pasien melalui jarum suntik sebagai pengukur kadar gula darah dalam tubuhnya[7]. Secara umum teknologi masa kini di buat secara otomatis[8]. Mencari alat yang mudah didapat dan murah dalam biaya karena berkaitan dengan masalah ekonomi[9].

Selanjutnya untuk pengukuran tekanan darah, biasanya oleh dokter diukur dengan alat ukut tensimeter yang mana hanya bisa dilakukan oleh para dokter atau bidan, sehingga orang pada umumnya tidak bisa mengecek tekanan darah sendiri. Dengan demikian perusahaan elekronik mulai mengembangkan alat ukur tekanan darah (tensimeter digital) yang praktis dan mudah digunakan. Peneliti juga mengembangkan alat ukur tekanan darah dengan berbagai mikrokontroller yang ada, selain harganya komponen yang dibilang tidak mahal dan gampang dicari. Selain itu, pemantauan detak jantung manusia juga telah dikembangkan dengan melampirkan sensor pulsa ke ujung jari tangan manusia pada alat ukur yang telah dibuat dan menampilkan hasil pengukuran pada tampilan alat ukur. Namun cara ini masih dianggap kurang efisien karena berat dan sebagainya [6]. Selain detak jantung, pengukuran kadar oksigen dalam darah sangatlah penting. Saat ini beberapa generasi penduduk di Indonesia telah mengembangkan teknologi oksimeter digital yang dilengkapi dengan bel untuk indikator yang mengingatkan jika ada penurunan saturasi oksigen dalam darah manusia [10].

Mikrokontroler NodeMCU adalah sebuah perkembangan dari mikrokontroler ESP8266 yang kemudian dikembangkan menjadi ESP8266 dimana modul mikrokontroller ini hampir menyerupai modul mikrokontroller arduino, tetapi dibedakan dengan fitur khusus untuk koneksi internet sehingga modul ini dapat berkomunikasi secara langsung dengan internet.

Sensor MAX30100 menggunakan mode reflectance, dimana LED merah, LED inframerah dan fotodiode diletakkan satu baris, seperti gambar sensor yang ditunjukkan oleh Gambar 2 serta cara penggunaan sensor ditunjukkan pada Gambar 1 [11].

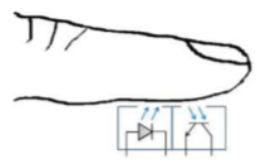

Gambar 1. Penguunaan Sensor MAX30100 [11]

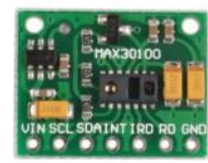

Gambar 2. Sensor MAX30100[11]

Pada gambar 1 jari diletakkan diatas sensor, kemudian cahaya dari LED merah dan LED inframerah akan memancar, kemudian gelombang cahaya dari LED inframerah akan diserap oleh darah jika mengandung banyak oksigen dan jika oksigen dalam darah berkurang maka gelombang cahaya LED merah akan diserap lebih banyak daripada LED inframerah. Gelombang cahaya yang tidak diserap akan dipantulkan kembali dan terdeteksi oleh fotodiode[6]. Sensor load cell digunakan untuk mendeteksi tekanan dan berat beban, sensor load cell digunakan sebagai sensor pada alat timbangan digital menggunakan prinsip tekanan. Sedangkan, modul penguat HX711 ini berfungsi sebagai amplifier dari hasil pembacaan sensor loadcell [12].
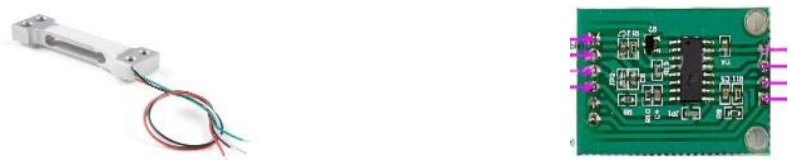

Gambar 3. Sensor Load Cell[13].

Gambar 4. Penguat HX711[13].

Sensor suhu DS18B20 adalah sensor cocok digunakan untuk mengukur suhu pada tempat yang sempit dan berair. Output data dari sensor DS18B20 adalah data digital. Dengan menggunakan kabel PVC maka sensor ini bisa mengukur suhu tidak melebihi $100{ }^{\circ} \mathrm{C}[14]$. 
Procedia of Engineering and Life Science Vol.1 No. 1 March 2021

Seminar Nasional \& Call for Paper Fakultas Sains dan Teknologi (SENASAINS $1^{\text {st }}$ )

Universitas Muhammadiyah Sidoarjo

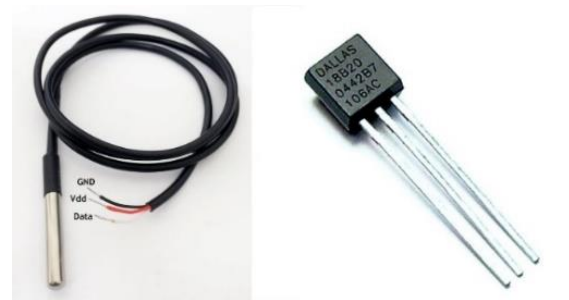

Gambar 5. Sensor Suhu DS18B20[14].

Perancangan yang dikembangkan yaitu dengan NodeMCU sebagai ikrokontroller yang mengolah data sensor MAX30100, sensor DS18B20 dan Load Cell + HX711. Semua hasil pengukuran akan tampil di LCD dan smartphone android yang terkoneksi dengan wifi atau internet. Alat ini akan dikemas dalam box sehingga bisa dibawa kemanamana dengan power supply portable power bank. Pengukuran dibidang kesehatan akan mudah dilakukan dengan dibuatnya alat ini.

\section{METODE PENELITIAN}

Pada penelitian ini, pengambilan data tersebut yaitu dengan melihat hasil data angka dengan memanfaatkan lcd dan smartphone. Mikrokontroller NodeMCU yang mempunyai pin I/O maka dapat membaca nilai yang dikirim oleh rangkaian serta terkoneksi dengan internet sehingga bisa menampilkan data berupa angka kedalam smartphone. Secara umum, pengembangan Rancang Bangun Monitoring Tekanan Darah, Gula Darah Non-Invasif, Berat, Dan Suhu Badan Berbasis Internet Of Things dilakukan beberapa tahapan, yaitu analisis, desain, pengembangan dan pengujian. Penelitian dilakukan dimulai dari analisis, yaitu menggunakan alat standar ketiga objek yang akan dikur dan mengidentifikasi kebutuhan rangkaian pada alat. Proses pengujian digunakan untuk mengetahui alat ini berfungsi dengan baik atau tidak.

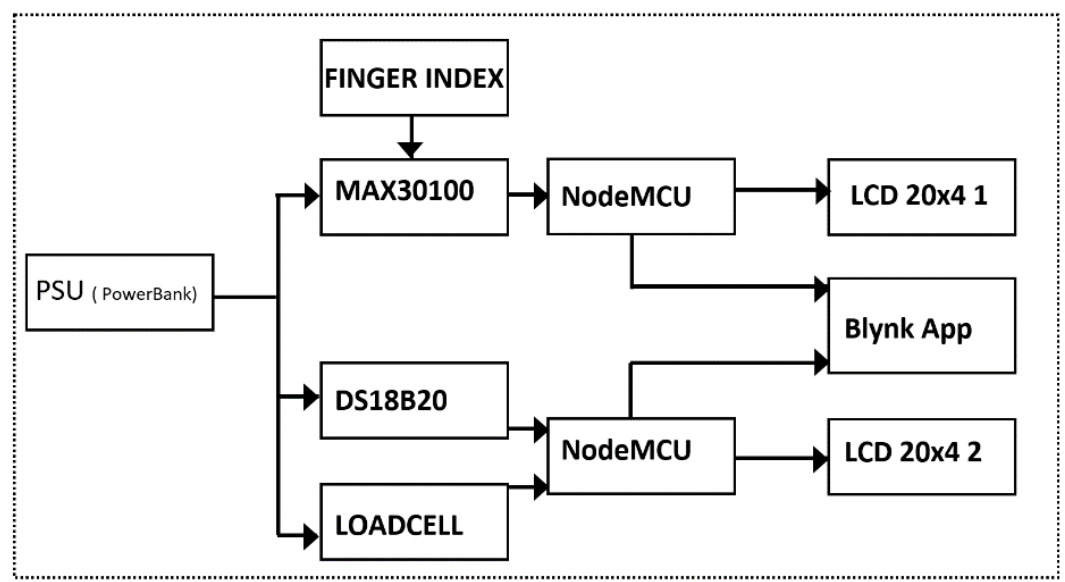

Gambar 6. Blok Diagram

Perancangan sistem sekarang menggunakan mikrokontroler NodeMCU. Mikrokontroler ini menggunakan koneksi wifi dan dapat diprogram menggunakan arduino.IDE. Alat ini mempunyai nilai tambah yaitu bisa ditampilkan pada android yang terkonoksi internet dan software yang dipakai adalah blynk. Hasil pengukuran tampil pada LCD 20x4 tang terpasang pada alat dan tampil juga di smartphone android yang dapat memudahkan dalam pembacaan nilai pada pengukuran. Pengembangan alat ini dari alat alat yang terpisah kemudian dijadikan 1 alat yang dibungkus rapi menggunakan box koper . 
Procedia of Engineering and Life Science Vol.1 No. 1 March 2021

Seminar Nasional \& Call for Paper Fakultas Sains dan Teknologi (SENASAINS $1^{\text {st }}$ )

Universitas Muhammadiyah Sidoarjo

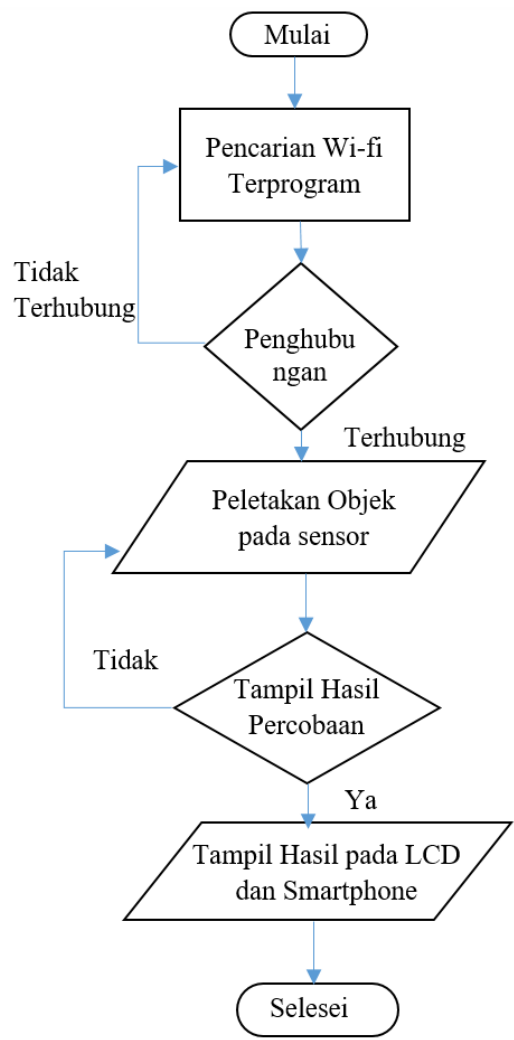

Gambar 7. Flow chart program

Penjelasan :

1. Mulai pada alat : Langkah awal yaitu dengan menekan tombol power untuk mengaktifkan alat.

2. Mencari perangkat wifi yang sudah terprogramkan pada alat.

3. Apabla tak terhubung, maka hal yang dilakukan adalah mengecek ulang username dan password yang digunakan.

4. Apabila sudah terhubung, maka objek siap diletakkan pada sesnor yang menyala.

5. Angka yang keluar dari alat adalah hasil yang diperoleh dari pembacaan sensor. Jika tidak keluar maka objek harus diletakkan pada sensor lagi.

6. Hasil pengukuran yang diinginkan akan tampil pada LCD 20x4 pada alat serta akan keluar juga hasil tersebut pada smartphone android.

7. Proses selesei.

\section{Hasil Serta Pembahasan}

Gambaran umum terkait alat yang dapat ditunjukkan pada Gambar 6. Blok Diagram meliputi :

1. Objek Finger Index sebagai input data;

2. Sensor MAX30100 untuk membaca data berupa objek finger index;

3. Sensor DS18B200 untuk membaca data suhu berupa objek badan manusia;

4. Sensor Load Cell serta penguat HX711 untuk membaca data berat badan berupa objek badan manusia;

5. NodeMCU ESP sebagai pengolah data semua sensor yang akan dikirimkan ke smartphone android, dan ditampilkan di LCD;

6. LCD 20x4 Sebagai tampilan alat ukur ini;

7. Blynk sebagai platform aplikasi android internet of things;

Hasil desain dapat ditunjukkan pada skema perancangan hardware yang disajikan pada Gambar 8 . 
Procedia of Engineering and Life Science Vol.1 No. 1 March 2021

Seminar Nasional \& Call for Paper Fakultas Sains dan Teknologi (SENASAINS $1^{\text {st }}$ )

Universitas Muhammadiyah Sidoarjo

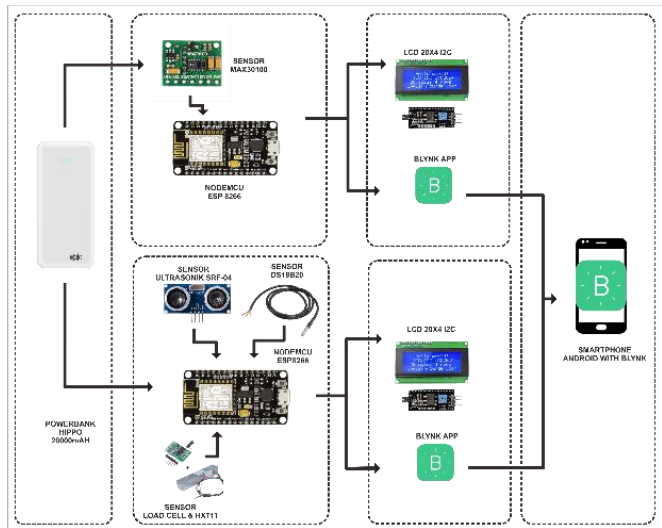

Gambar 8. perancangan hardware

Sesuai dengan perancangan diatas, wiring ragkaian keseluruhan ditunjukkan pada Gambar 9. Gambar menunjukkan keseluruhan rangkaian dari alat tersebut. Terdiri dari power bank, NodeMCU, sensor MAX 301000, Sensor DS18B20, Sensor Load Cell dilengkapi penguat HX711 dan LCD 20x4.

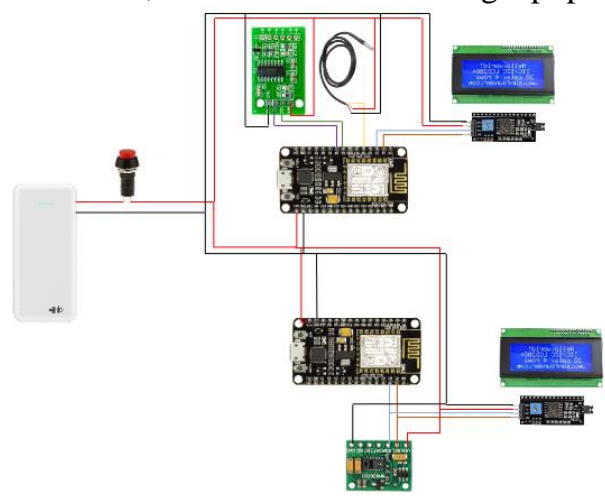

Gambar 9. Wiring rangkaian keseluruhan

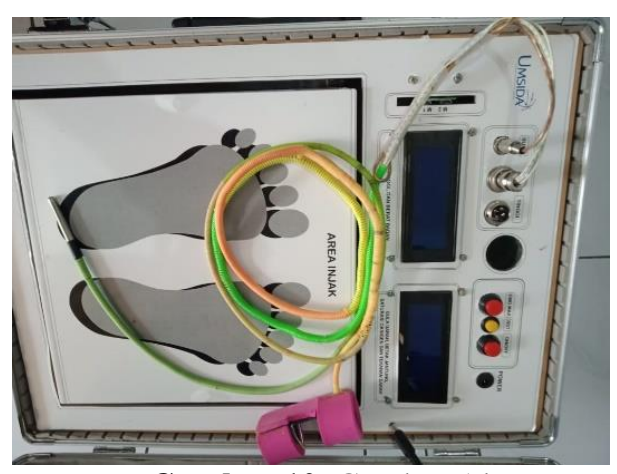

Gambar 10. Gambar Alat

Pengujian sensor MAX 30100 dilakukan untuk mengetahui keakurasian sensor apakah pengukuran tekanan darah, gula darah terhadap sensor sesuai dengan pengukuran pada alat pabrikan.

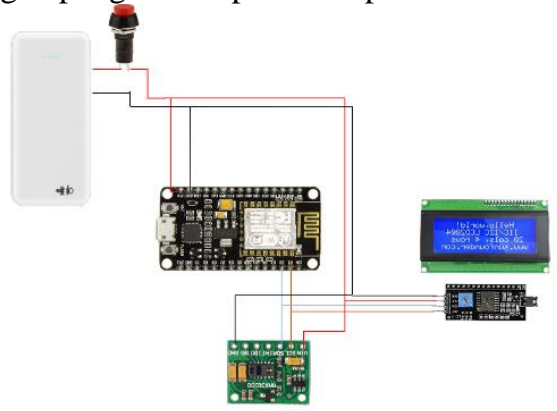

Gambar 11. Rangkaian NodeMCU dan sensor MAX30100

Tabel 1. Tabel pengujian sensor MAX30100 untuk mengukur gula darah secara non invasif.

\begin{tabular}{|c|c|c|c|c|c|c|c|c|c|c|c|c|c|c|c|}
\hline \multirow[t]{3}{*}{$\begin{array}{l}\text { Pasien } \\
\text { Ke }\end{array}$} & \multicolumn{3}{|c|}{$\begin{array}{l}\text { Nama Pasien dan } \\
\text { Parameternya }\end{array}$} & \multirow{3}{*}{$\begin{array}{c}\text { Gula } \\
\text { Darah } \\
\text { Normal } \\
\mathrm{mg} / \mathrm{dl}\end{array}$} & \multicolumn{6}{|c|}{$\begin{array}{c}\text { Sensor } M A X 30100 \text { dan Kadar Gula Darah } \\
\text { PERCOBAAN }\end{array}$} & \multirow[t]{2}{*}{$\begin{array}{l}\text { Rata- } \\
\text { Rata }\end{array}$} & \multirow[t]{2}{*}{ Deviasi } & \multirow[t]{2}{*}{$\begin{array}{l}\text { Standar } \\
\text { Deviasi }\end{array}$} & \multirow[t]{2}{*}{$\begin{array}{c}\text { Akurasi } \\
\text { Alat }\end{array}$} & \multirow{3}{*}{$\begin{array}{c}\text { Kondisi } \\
\text { Gula } \\
\text { Darah }\end{array}$} \\
\hline & \multirow{2}{*}{$\begin{array}{l}\text { Nama } \\
\text { Pasien }\end{array}$} & Berat & Usia & & Alat Stdr & 1 & 2 & 3 & 4 & 5 & & & & & \\
\hline & & $\mathrm{Kg}$ & (Thn) & & $\mathrm{mg} / \mathrm{dl}$ & $\mathrm{mg} / \mathrm{dl}$ & $\mathrm{mg} / \mathrm{dl}$ & $\mathrm{mg} / \mathrm{dl}$ & $\mathrm{mg} / \mathrm{dl}$ & $\mathrm{mg} / \mathrm{dl}$ & $\mathrm{mg} / \mathrm{dl}$ & $\mathrm{mg} / \mathrm{dl}$ & & $\%$ & \\
\hline 1. & Muhammad & 46,20 & 20 & $70-200$ & 137 & 131 & 140 & 141 & 134 & 131 & 135,40 & 1,60 & 4,83 & 98,83 & Normal \\
\hline 2. & Hussein & 63,30 & 21 & $70-200$ & 121 & 126 & 120 & 132 & 144 & 141 & 132,60 & 11,60 & 10,04 & 90,41 & Normal \\
\hline 3. & Eko Agus & $85^{\circ} 70$ & 32 & $70-200$ & 123 & 135 & 127 & 111 & 144 & 140 & 131,40 & 8,40 & 13,05 & 93,17 & Normal \\
\hline 4 & Fariz & 51,00 & 21 & $70-200$ & 99 & 102 & 106 & 106 & 110 & 91 & 103,00 & 4,00 & 7,28 & 95,96 & Normal \\
\hline 5 & Rossadi & 78,00 & 52 & $70-200$ & 168 & 152 & 160 & 159 & 154 & 152 & 155,40 & 12,60 & 3,85 & 92,50 & Normal \\
\hline 6 & Chomariyah & 61,00 & 40 & $70-200$ & 163 & 136 & 158 & 158 & 154 & 142 & 149,60 & 13,40 & 10,04 & 91,78 & Normal \\
\hline 7 & Muslikha & 51,70 & 65 & $70-200$ & 237 & 237 & 242 & 236 & 256 & 248 & 243,80 & 6,80 & 8,32 & 97,13 & Tinggi \\
\hline 8 & M.Awar B. & 84,20 & 21 & $70-200$ & 109 & 130 & 110 & 133 & 128 & 121 & 124,40 & 15,40 & 9,18 & 85,87 & Normal \\
\hline \multicolumn{4}{|c|}{ Rata-Rata Keseluruhan } & & 144,63 & & & & & & 133,11 & 9,23 & 8,32 & 93,21 & \\
\hline
\end{tabular}


Procedia of Engineering and Life Science Vol.1 No. 1 March 2021

Seminar Nasional \& Call for Paper Fakultas Sains dan Teknologi (SENASAINS $1^{\text {st }}$ )

Universitas Muhammadiyah Sidoarjo

Pada Tabel Pengujian 1, dimana didapatkan rata-rata deviasi dari sensor adalah 9,32, dan standar deviasi adalah 8,32. Akurasi sensor dengan alat standart sebesar 93,21\%. Jadi pada pengujian sensor Max30100 yang dibandingkan alat standart memperlihatkan nilai yang jauh.

Tabel 2. Tabel pengujian sensor MAX30100 untuk mengukur tekanan darah (Systole).

\begin{tabular}{|c|c|c|c|c|c|c|c|c|c|c|c|c|c|c|}
\hline \multirow[t]{3}{*}{$\begin{array}{c}\text { Pasien } \\
\text { Ke }\end{array}$} & \multicolumn{3}{|c|}{$\begin{array}{l}\text { Nama Pasien dan } \\
\text { Parameternya }\end{array}$} & \multicolumn{6}{|c|}{$\begin{array}{c}\text { Sensor } M A X 30100 \text { dan Tekanan Darah(Systole) } \\
\text { PERCOBAAN }\end{array}$} & \multirow[t]{2}{*}{$\begin{array}{l}\text { Rata- } \\
\text { Rata }\end{array}$} & \multirow[t]{2}{*}{ Deviasi } & \multirow[t]{2}{*}{$\begin{array}{l}\text { Standar } \\
\text { Deviasi }\end{array}$} & \multirow[t]{2}{*}{$\begin{array}{c}\text { Akurasi } \\
\text { Alat }\end{array}$} & \multirow[t]{2}{*}{$\begin{array}{l}\text { Kondisi } \\
\text { Systole }\end{array}$} \\
\hline & \multirow[t]{2}{*}{$\begin{array}{l}\text { Nama } \\
\text { Pasien }\end{array}$} & Usia & $\begin{array}{l}\text { Systole } \\
\text { Normal }\end{array}$ & Alat Stdr & 1 & 2 & 3 & 4 & 5 & & & & & \\
\hline & & Tahun & $\mathrm{L} / \mathrm{P}$ & $\mathrm{mmHg}$ & $\mathrm{mmHg}$ & $\mathrm{mmHg}$ & $\mathrm{mmHg}$ & $\mathrm{mmHg}$ & $\mathrm{mmHg}$ & $\mathrm{mmHg}$ & $\mathrm{mmHg}$ & & $\%$ & \\
\hline 1. & Muhammad & 20 & $85-140$ & 109 & 104 & 118 & 115 & 106 & 99 & 108,40 & 0,60 & 7,89 & 99,45 & Normal \\
\hline 2. & Hussein B.S & 21 & $85-140$ & 149 & 120 & 142 & 133 & 136 & 140 & 134,20 & 14,80 & 8,67 & 90,07 & Tinggi \\
\hline 3. & Eko Agus S & 32 & $85-140$ & 132 & 128 & 140 & 121 & 138 & 110 & 127,40 & 4,60 & 12,40 & 96,52 & Normal \\
\hline 4 & Fariz & 21 & $85-140$ & 106 & 102 & 104 & 108 & 109 & 86 & 101,80 & 4,20 & 9,28 & 96,04 & Normal \\
\hline 5 & Rossadi & 52 & $85-140$ & 133 & 122 & 125 & 126 & 124 & 117 & 122,80 & 10,20 & 3,56 & 92,33 & Normal \\
\hline 6 & Chomariyah & 40 & $85-140$ & 136 & 156 & 153 & 74 & 75 & 165 & 124,60 & 11,40 & 45,95 & 91,62 & Normal \\
\hline 7 & Muslikha & 65 & $85-140$ & 127 & 119 & 128 & 116 & 129 & 138 & 126,00 & 1,00 & 8,75 & 99,21 & Normal \\
\hline 8 & M.Awar B. & 21 & $85-140$ & 135 & 125 & 110 & 132 & 122 & 139 & 125,60 & 9,40 & 10,92 & 93,04 & Normal \\
\hline \multicolumn{4}{|c|}{ Rata-Rata Keseluruhan } & 128,38 & & & & & & 12069 & 7,03 & 13,43 & 94,78 & \\
\hline
\end{tabular}

Pada Tabel Pengujian 2, dimana didapatkan rata-rata deviasi dari sensor adalah 7,03, dan standar deviasi adalah 13,43. Akurasi sensor dengan alat standart sebesar 94,78 \%. Jadi pada pengujian sensor Max30100 yang dibandingkan alat standart memperlihatkan nilai yang hampir sama.

Tabel 3. Tabel pengujian sensor MAX30100 untuk mengukur tekanan darah(Diastole).

\begin{tabular}{|c|c|c|c|c|c|c|c|c|c|c|c|c|c|c|}
\hline \multirow{4}{*}{$\begin{array}{c}\text { Pasien } \\
\mathbf{K e}\end{array}$} & \multirow{2}{*}{\multicolumn{3}{|c|}{$\begin{array}{l}\text { Nama Pasien dan } \\
\text { Parameternya }\end{array}$}} & \multirow{2}{*}{\multicolumn{6}{|c|}{$\begin{array}{c}\text { Sensor } M A X 30100 \text { dan Tekanan Darah(Diastole) } \\
\text { PERCOBAAN }\end{array}$}} & \multirow{3}{*}{$\begin{array}{l}\text { Rata- } \\
\text { Rata }\end{array}$} & \multirow[t]{3}{*}{ Deviasi } & \multirow{3}{*}{$\begin{array}{l}\text { Standar } \\
\text { Deviasi }\end{array}$} & \multirow{3}{*}{$\begin{array}{c}\text { Akurasi } \\
\text { Alat }\end{array}$} & \multirow{3}{*}{$\begin{array}{l}\text { Kondisi } \\
\text { Diastole }\end{array}$} \\
\hline & & & & & & & & & & & & & & \\
\hline & \multirow[t]{2}{*}{$\begin{array}{l}\text { Nama } \\
\text { Pasien }\end{array}$} & Usia & $\begin{array}{l}\text { Diastole } \\
\text { Normal }\end{array}$ & Alat Stdr & 1 & 2 & 3 & 4 & 5 & & & & & \\
\hline & & Tahun & mmhg & $\mathrm{mmHg}$ & $\mathrm{mmHg}$ & $\mathrm{mmHg}$ & $\mathrm{mmHg}$ & $\mathrm{mmHg}$ & $\mathrm{mmHg}$ & $\mathrm{mmHg}$ & $\mathrm{mmHg}$ & & $\%$ & \\
\hline 1. & Muhammad & 20 & $55-99$ & 76 & 73 & 76 & 73 & 69 & 57 & 69,60 & 6,40 & 7,47 & 91,58 & Normal \\
\hline 2. & Hussein B.S & 21 & $55-99$ & 76 & 98 & 100 & 80 & 58 & 56 & 78,40 & 2,40 & 21,04 & 96,84 & Normal \\
\hline 3. & Eko Agus $\mathrm{S}$ & 32 & $55-99$ & 77 & 68 & 70 & 80 & 68 & 80 & 73,20 & 3,80 & 6,26 & 95,06 & Normal \\
\hline 4 & Fariz & 21 & $55-99$ & 65 & 57 & 59 & 63 & 64 & 61 & 60,80 & 4,20 & 2,86 & 93,54 & Normal \\
\hline 5 & Rossadi & 52 & $55-99$ & 82 & 77 & 80 & 81 & 79 & 72 & 77,80 & 4,20 & 3,56 & 94,88 & Normal \\
\hline 6 & Chomariyah & 40 & $55-99$ & 87 & 111 & 128 & 29 & 30 & 120 & 83,60 & 3,40 & 49,75 & 96,09 & Normal \\
\hline 7 & Muslikha & 65 & $55-90$ & 80 & 64 & 73 & 61 & 74 & 83 & 71,00 & 9,00 & 8,75 & 88,75 & Normal \\
\hline 8 & M.Awar B. & 21 & $55-99$ & 84 & 80 & 70 & 79 & 77 & 73 & 75,80 & 8,20 & 4,21 & 90,24 & Normal \\
\hline \multicolumn{4}{|c|}{ Rata-Rata Keseluruhan } & 78,14 & & & & & & 73,78 & 5,20 & 12,99 & 93,37 & \\
\hline
\end{tabular}

Pada Tabel Pengujian 3, dimana didapatkan rata-rata deviasi dari sensor adalah 5,2, dan standar deviasi adalah 12,99. Akurasi sensor dengan alat standart sebesar 93,37\%. Jadi pada pengujian sensor Max30100 yang dibandingkan alat standart tensimeter digital memperlihatkan nilai yang hampir sama.

Pengujian sensor DS18B20 dilakukan untuk mengetahui suhu badan secara realtime. Pengujian sensor loadcell dan penguat HX711 dilakukan untuk mengetahui keakurasian berat badan dalam pengukuran menggunakan alat dan timbagan digital.

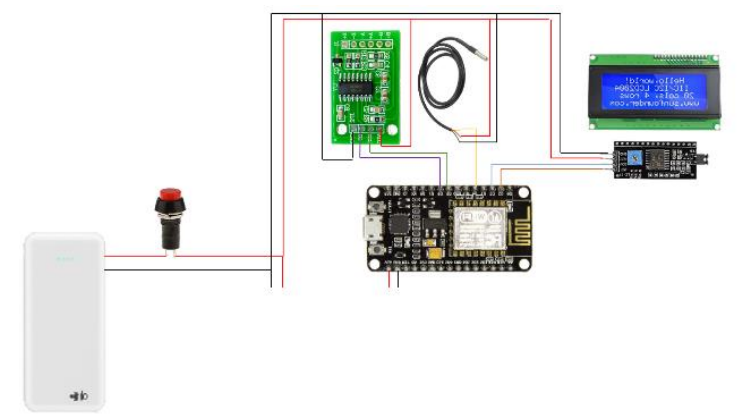

Gambar 12. Rangkaian NodeMCU sensor Load Cell dan sensor DS18B20 
Procedia of Engineering and Life Science Vol.1 No. 1 March 2021

Seminar Nasional \& Call for Paper Fakultas Sains dan Teknologi (SENASAINS $1^{\text {st }}$ ) Universitas Muhammadiyah Sidoarjo

Tabel 4. Tabel pengujian sensor DS18B20 untuk mendeteksi suhu badan secara realtime

\begin{tabular}{|c|c|c|c|c|c|c|c|c|c|c|c|c|c|c|}
\hline \multirow[t]{4}{*}{$\begin{array}{c}\text { Pasien } \\
\text { Ke }\end{array}$} & \multirow{2}{*}{\multicolumn{3}{|c|}{$\begin{array}{c}\text { Nama Pasien dan } \\
\text { Parameternya }\end{array}$}} & \multirow{2}{*}{\multicolumn{6}{|c|}{$\begin{array}{c}\text { Sensor DS18B20 dan Thermometer digital (Suhu } \\
\text { Badan) }\end{array}$}} & \multirow[t]{3}{*}{$\begin{array}{l}\text { Rata- } \\
\text { Rata }\end{array}$} & \multirow[t]{3}{*}{ Deviasi } & \multirow[t]{3}{*}{$\begin{array}{l}\text { Standar } \\
\text { Deviasi }\end{array}$} & \multirow[t]{3}{*}{$\begin{array}{c}\text { Akurasi } \\
\text { Alat }\end{array}$} & \multirow{3}{*}{$\begin{array}{c}\text { Kondisi } \\
\text { Suhu } \\
\text { Tubuh }\end{array}$} \\
\hline & & & & & & & & & & & & & & \\
\hline & \multirow[t]{2}{*}{$\begin{array}{l}\text { Nama } \\
\text { Pasien }\end{array}$} & Usia & $\begin{array}{c}\text { Suhu } \\
\text { Normaal }\end{array}$ & $\begin{array}{l}\text { Alat } \\
\text { Stdr }\end{array}$ & 1 & 2 & 3 & 4 & 5 & & & & & \\
\hline & & Tahun & $\left({ }^{\circ} \mathrm{C}\right)$ & $\left({ }^{\circ} \mathrm{C}\right)$ & $\left({ }^{\circ} \mathrm{C}\right)$ & $\left({ }^{\circ} \mathrm{C}\right)$ & $\left({ }^{\circ} \mathrm{C}\right)$ & $\left({ }^{\circ} \mathrm{C}\right)$ & $\left({ }^{\circ} \mathrm{C}\right)$ & $\left({ }^{\circ} \mathrm{C}\right)$ & $\left({ }^{\circ} \mathrm{C}\right)$ & & $\%$ & \\
\hline 1. & Muhammad & 20 & $36-37,5$ & 36,30 & 33,0 & 34,0 & 33,0 & 36,0 & 36,0 & 34,40 & 1,90 & 1,52 & 94,77 & Normal \\
\hline 2. & Hussein B.S & 21 & $36-37,5$ & 36,70 & 34,0 & 35,0 & 35,0 & 35,0 & 35,0 & 34,80 & 1,90 & 0,45 & 94,82 & Normal \\
\hline 3. & Eko Agus S & 32 & $36-37,5$ & 36,20 & 35,0 & 36,0 & 36,0 & 36,0 & 36,0 & 35,80 & 0,40 & 0,45 & 98,90 & Normal \\
\hline 4 & Fariz & 21 & $36-37,5$ & 36,00 & 35,3 & 35,3 & 35,0 & 35,0 & 35,0 & 35,13 & 0,87 & 0,18 & 97,58 & Normal \\
\hline 5 & Rossadi & 52 & $36-37,5$ & 35,7 & 35,6 & 35,6 & 35,6 & 35,5 & 35,5 & 35,55 & 0,15 & 0,05 & 99,59 & Rendah \\
\hline 6 & Chomariyah & 40 & $36-37,5$ & 36,00 & 33,0 & 33,0 & 33,0 & 33,0 & 33,0 & 33,00 & 3,00 & 0,00 & 91,67 & Normal \\
\hline 7 & Muslikha & 65 & $36-37,5$ & 35,40 & 34,7 & 34,6 & 34,4 & 34,2 & 34,3 & 34,44 & 0,96 & 0,20 & 97,28 & Rendah \\
\hline $\mathbf{8}$ & M.Awar B. & 21 & $36-37,5$ & 36,20 & 34,0 & 36,0 & 36,0 & 36,0 & 35,0 & 35,40 & 0,80 & 0,89 & 97,79 & Normal \\
\hline \multicolumn{4}{|c|}{ Rata-Rata Keseluruhan } & 36,06 & & & & & & 34,81 & 1,25 & 0,47 & 96,55 & \\
\hline
\end{tabular}

Pada Tabel Pengujian 4, dimana didapatkan rata-rata deviasi dari sensor adalah 1,25, dan standar deviasi adalah 0,47. Akurasi sensor dengan alat standart sebesar 96,55\%. Jadi pada pengujian sensor suhu yang dibandingkan alat standart thermometer digital memperlihatkan nilai yang hampir sama.

Tabel 5. Tabel pengujian sensor Loadcell dan penguat HX711 pada pengukuran berat badan.

\begin{tabular}{|c|c|c|c|c|c|c|c|c|c|c|c|c|c|}
\hline \multirow{4}{*}{$\begin{array}{c}\text { Pasien } \\
\text { Ke }\end{array}$} & \multirow{2}{*}{\multicolumn{3}{|c|}{ Nama Pasien dan Parameternya }} & \multirow{2}{*}{\multicolumn{6}{|c|}{$\begin{array}{c}\text { Sensor Load Cell dan timbangan digital(Berat) } \\
\text { PERCOBAAN }\end{array}$}} & \multirow{3}{*}{$\begin{array}{l}\text { Rata-Rata } \\
\text { sensor } \\
\text { Load Cell }\end{array}$} & \multirow[t]{3}{*}{ Deviasi } & \multirow{3}{*}{$\begin{array}{c}\text { Standar } \\
\text { Deviasi } \\
\text { Load Cell }\end{array}$} & \multirow[t]{3}{*}{ Akurasi Alat } \\
\hline & & & & & & & & & & & & & \\
\hline & \multirow[t]{2}{*}{$\begin{array}{l}\text { Nama } \\
\text { Pasien }\end{array}$} & $\begin{array}{c}\text { Jenis } \\
\text { Kelamin }\end{array}$ & Usia & $\begin{array}{l}\text { Alat } \\
\text { Stdr }\end{array}$ & 1 & 2 & 3 & 4 & 5 & & & & \\
\hline & & $\mathrm{L} / \mathrm{P}$ & (Thn) & $\mathrm{Kg}$ & $\mathrm{Kg}$ & $\mathrm{Kg}$ & $\mathrm{Kg}$ & $\mathrm{Kg}$ & $\mathrm{Kg}$ & $\mathrm{Kg}$ & $\mathrm{Kg}$ & & $\mathrm{Kg}$ \\
\hline 1. & Muhammad & $\mathrm{L}$ & 20 & 46,20 & 46 & 47 & 46 & 44 & 46 & 45,80 & 0,40 & 1,10 & 99,13 \\
\hline 2. & Hussein B.S & $\mathrm{L}$ & 21 & 63,30 & 62 & 63 & 62 & 62 & 63 & 62,40 & 0,90 & 0,55 & 98,58 \\
\hline 3. & Eko Agus $\mathrm{S}$ & $\mathrm{L}$ & 32 & 85,70 & 83 & 85 & 85 & 84 & 85 & 84,40 & 1,30 & 0,89 & 98,48 \\
\hline 4 & Fariz & $\mathrm{L}$ & 21 & 51,00 & 50 & 50 & 50 & 50 & 50 & 50,00 & 1,00 & 0,00 & 98,04 \\
\hline 5 & Rossadi & $\mathrm{L}$ & 52 & 78,00 & 77 & 77 & 77 & 77 & 77 & 77,00 & 1,00 & 0,00 & 98,72 \\
\hline 6 & Chomariyah & $\mathrm{P}$ & 40 & 61,00 & 60 & 60 & 60 & 60 & 60 & 60,00 & 1,00 & 0,00 & 98,36 \\
\hline 7 & Muslikha & $\mathrm{P}$ & 65 & 51,70 & 51 & 51 & 51 & 51 & 51 & 51,00 & 0,70 & 0,00 & 98,65 \\
\hline $\mathbf{8}$ & M.Awar B. & L & 21 & 84,20 & 81 & 81 & 81 & 81 & 81 & 81,00 & 3,20 & 0,00 & 96,20 \\
\hline \multicolumn{4}{|c|}{ Rata-Rata Keseluruhan } & 65,14 & & & & & & 65,95 & 1,19 & 0,32 & 98,27 \\
\hline
\end{tabular}

Pada Tabel Pengujian 5, dimana didapatkan rata-rata deviasi dari sensor adalah 1,19, dan standar deviasi adalah 0,32. Akurasi sensor dengan alat standart sebesar $98,27 \%$. Jadi pada pengujian sensor load cell yang dibandingkan alat standart memperlihatkan nilai yang hampir sama.

Pengujian pembacaan data menggunakan internet dilakukan untuk mengetahui kinerja NodeMCU tersambung atau tidaknya dengan smartphone android pada saat proses pengujian jarak hasil pembacaan aplikasi blynk di smartphone android dengan mikrokontroller NodeMCU harus di sinkronkan terlebih dahulu agar pembacaan terca di smatphone. Tabel 1. menunjukkan pengujian mengenai hasil yang sudah diolah NodeMCU yang dikirm ke smartphone android mengunakan internet.

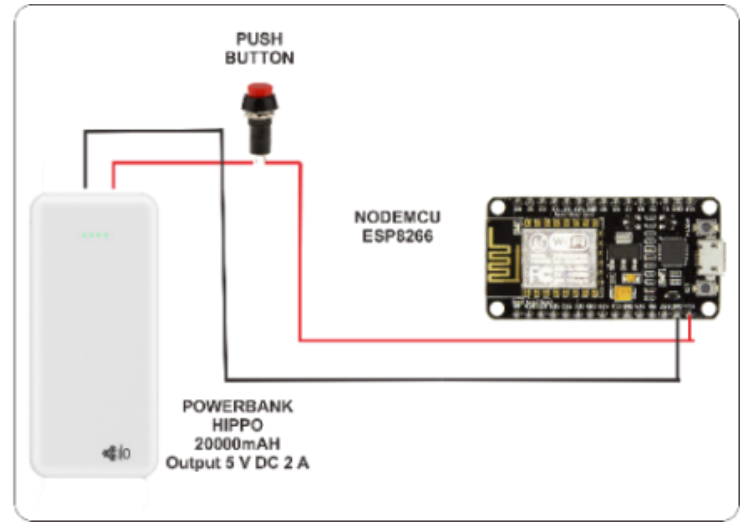

Gambar 13. Rangkaian NodeMCU 
Procedia of Engineering and Life Science Vol.1 No. 1 March 2021

Seminar Nasional \& Call for Paper Fakultas Sains dan Teknologi (SENASAINS $1^{\text {st }}$ )

Universitas Muhammadiyah Sidoarjo

Tabel 6. Hasil Pengujian Internet Of Things

\begin{tabular}{|c|c|c|c|c|c|c|c|c|c|c|}
\hline \multirow[t]{2}{*}{ NO } & \multirow[t]{2}{*}{ Tipe Hр } & \multirow{2}{*}{$\begin{array}{l}\text { Jarak } \\
\mathbf{K m}\end{array}$} & \multicolumn{5}{|c|}{ Percobaan Ke- } & \multirow{2}{*}{$\begin{array}{l}\text { Rata - } \\
\text { rata }\end{array}$} & \multirow{2}{*}{$\begin{array}{l}\text { Standart } \\
\text { Deviasi }\end{array}$} & \multirow[t]{2}{*}{ Tempat } \\
\hline & & & 1 & 2 & 3 & 4 & 5 & & & \\
\hline 1 & $\begin{array}{l}\text { Wikko Harry } \\
\text { OS Android } 7.0 \text { (Nouget) } \\
\text { CPU Quad-core } 1.3 \mathrm{GHz} \text { Cortex-A7 } \\
\text { ROM 16GB 3GB RAM } \\
\text { WLAN Wi-Fi } 802.11 \mathrm{~b} / \mathrm{g} / \mathrm{n} \text {, Wi-Fi Direct, hotspot }\end{array}$ & 18 & 1 & 1 & 1 & 1 & 1 & 1 & 0 & $\begin{array}{l}\text { Kepulungan - } \\
\text { Universitas } \\
\text { Muhammadiyah } \\
\text { Sidoarjo } \\
\text { Kampus } 2\end{array}$ \\
\hline 2 & $\begin{array}{l}\text { OPPO A12 } \\
\text { OS Android } 9.0 \text { (Pie) } \\
\text { CPU Octa-core( } 4 \times 2.35 \mathrm{~Hz} \text { Cortex-A53) } \\
\text { ROM } 64 \mathrm{~GB} \text { RAM } 4 \mathrm{~GB} \\
\text { WLAN Wi-Fi } 802.11 \mathrm{~b} / \mathrm{g} / \mathrm{n} \text {, dual band, Wi-Fi Direct, hotspot }\end{array}$ & 6,2 & 1 & 1 & 1 & 1 & 1 & 1 & 0 & $\begin{array}{l}\text { Kepulungan } \\
\text { Gempol - } \\
\text { Masjid Kuti } \\
\text { Pandaan }\end{array}$ \\
\hline 3 & $\begin{array}{l}\text { Readmi Note } 8 \\
\text { OS Android } 9.0(\mathrm{Pie}) \\
\text { CPU Octa-core }(4 \times 2.0 \mathrm{~Hz} \text { Kryo } 260 \text { Gold }) \\
\text { ROM } 64 \mathrm{~GB} \text { RAM } 4 \mathrm{~GB} \\
\text { WLAN Wi-Fi } 802.11 \mathrm{~b} / \mathrm{g} / \mathrm{n} \text {, dual band, Wi-Fi Direct, hotspot }\end{array}$ & 866 & 1 & 1 & 1 & 1 & 1 & 1 & 0 & $\begin{array}{l}\text { Kepulungan } \\
\text { Gempol - } \\
\text { Makasar } \\
\text { Sulawesi } \\
\text { Selatan }\end{array}$ \\
\hline
\end{tabular}

Berdasarkan pada Tabel Pengujian 6 dilihat bahwa pada Kepulungan Gempol menuju Maksar Sulawesi Selatan dengan jarak $866 \mathrm{Km}$ alat masih terhubung dengan aplikasi blynk. Dengan spesifikasi handphone yang berbeda tidak mempengaruhi aplikasi tersebut karena selama ada jaringan internet, alat tersebut kan terhubung dengan aplikasi blynk.

\section{KESIMPULAN}

Setelah dilakukan prosese pengujian dan pengambilan data selama beberapa kali dapat disimpulkan bahwa Rancang Bangun MonitoringTekanan Darah, Gula Darah Non-Invasif, Berat, Dan Suhu Badan Berbasis Internet Of Things ini mengukur orang dewasa. Dimana tingkat akurasi setiap sensor berfungsi sangat baik dengan tingkat akurasi sensor MAX30100 dalam mengukur gula darah mencapai 93,21\%, mengukur tekanan darah(Systole) mencapai 94,78\%, mengukur tekanan darah(diastole) mencapai 93,37 \%, Sensor Load Cell atau Sensor Berat Badan mencapai 98,27\% dan Sensor Ds18b20 (suhu) mencapai 96,55 \%. Dari percobaan diatas memperlihatkan bahwa keempat sensor yang digunakan memiliki akurasi yang tinggi. Mikrokontroller Nodemcu yang digunakan pada rancang bangun monitoring tekanan darah, gula darah non-invasif, berat, suhu badan berbasis Internet Of Things ini berfungsi sangat baik dalam pengiriman data menggunakan koneksi internet, dilihat dari pengujian yang berbeda pada jarak yang tidak terbatas selama alat terkoneksi internet.

\section{REFERENSI}

[1] M. A. Mahmud, K. Bates, T. Wood, A. Abdelgawad, and K. Yelamarthi, “A complete Internet of Things (IoT) platform for Structural Health Monitoring (SHM)," IEEE World Forum Internet Things, WF-IoT 2018 - Proc., vol. 2018-Janua, pp. 275-279, 2018, doi: 10.1109/WF-IoT.2018.8355094.

[2] E. Agus Suprayitno, A. Setiawan, and R. Dijaya, "Design of Instrumentation in Detecting Blood Sugar Levels with Non-Invasive Technique Base on IoT (Internet of Things),” Int. J. Eng. Technol., vol. 7, no. 4.15, p. 440, 2018, doi: 10.14419/ijet.v7i4.15.25252.

[3] 2017 Internasional of Diabetic Federation, Eighth edition 2017. 2017.

[4] D. T. Dirta and Suyanto, "Rancang Bangun Sistem Transmisi Data Tekanan Darah untuk Mendukung Human Health Monitoring Berbasis Pada Mobile Platform Android,” J. Tek. POMITS, vol. 2, no. 2, pp. 189-194, 2013.

[5] F. M. Kandou, D. Bahrun, M. Kes, S. R. U. A. Sompie, and I. B. S. Narasiang, "Rancang Bangun Alat Ukur Tekanan Darah Manusia Menggunakan Sensor 2SMPP Yang Dapat Menyimpan Data," E-Journal Tek. Elektro Dan Komput., vol. 3, no. 4, pp. 57-64, 2014.

[6] E. A. Suprayitno, M. R. Marlianto, and M. I. Mauliana, "Measurement device for detecting oxygen saturation in blood, heart rate, and temperature of human body," J. Phys. Conf. Ser., vol. 1402, no. 3, 2019, doi: 10.1088/17426596/1402/3/033110.

[7] Rokhmah NS, “Ternyata Jus (Minuman) dari Kulit Manggis Mempunyai Efek Samping,” Kompasiana, vol. 3, no. 3, pp. 4665-4668, 2015.

[8] J. Jamaaluddin, "Sistem Kontrol Pendingin Mobil Ramah Lingkungan Berbasis Android,” Cyclotron, vol. 2, 
Procedia of Engineering and Life Science Vol.1 No. 1 March 2021

Seminar Nasional \& Call for Paper Fakultas Sains dan Teknologi (SENASAINS $1^{\text {st }}$ )

Universitas Muhammadiyah Sidoarjo

no. 1, 2019, doi: 10.30651/cl.v2i1.2528.

[9] Jamaaluddin, I. Robandi, and I. Anshory, "A very short-term load forecasting in time of peak loads using interval type-2 fuzzy inference system: A case study on java bali electrical system," J. Eng. Sci. Technol., 2019.

[10] Y. Jawahar, "Design of an Infrared based Blood Oxygen Saturation and Heart Rate Monitoring Device," p. 69, 2009.

[11] A. N. Qahar, "Desain Alat Ukur Denyut Jantung Dan Saturasi Oksigen Pada Anak Menggunakan Satu Sensor," pp. 4-7, 2018.

[12] E. A. S. Tri Hamdani Agung Cahyono, "Alat Ukur Berat Badan, Tinggi Badan dan Suhu Badan di Posyandu Berbasis Android," Elinvo (Electronics, Informatics, Vocat. Educ., vol. 3, no. 1, pp. 25-30, 2018, doi: 10.21831/elinvo.v3i1.20221.

[13] T. Czle, Button Load Cell, Load and C. Amplifier, "Load cell sensor 24 bit ADC - HX711," Load cell Sens. 24 bit ADC - HX711, 2017.

[14] I. Sulistiyowati, A. R. Sugiarto, and J. Jamaaluddin, "Smart Laboratory Based on Internet of Things in the Faculty of Electrical Engineering, University of Muhammadiyah Sidoarjo," IOP Conf. Ser. Mater. Sci. Eng., vol. 874, no. 1, 2020, doi: 10.1088/1757-899X/874/1/012007. 